\title{
NOTES
}

\section{THE PARENTHETICAL MODE OF WHITMAN'S "WHEN I READ THE BOOK"}

Although it has been occasionally anthologized, the 1871 version of "When I Read the Book" has been neglected in critical discussions of Whitman's poetry. Positioned among the prefatory matter of Leaves of Grass, this verse has been approached as a specific intimation of the poet's homosexuality or as a general admonition to biographically-minded readers concerning the limitations of assessing any person's life on the basis of material facts, ${ }^{1}$ but it has not been sufficiently appreciated as an example of Whitman's art. Among the likely reasons for this neglect are the many unconventional features of this work, including an odd trailing off into a ruminative parenthetical aside, which may seem extreme even within the context of Whitman's numerous other revisions of verse traditions. Whitman's occasional "ending of a poem with a question is a tricky maneuver that does not always work," C. Carroll Hollis observes, ${ }^{2}$ and the poet's ending of "When I Read the Book" with a parenthetical expression seems to have been equally risky. This poem, however, merits reconsideration, especially in terms of the implications of its emphasis on a particular rhetorical device. The seemingly unaesthetic form of "When I Read the Book," as we will see, expresses the ambiguous rhetorical capacity of the parenthetical insertion to serve as either a digression from or an amplification of a main theme. The parenthetical mode of the poet's search for a main theme in this poem is aligned with the Transcendentalist notion, as particularly expressed by Thoreau, that a life "is only great-circle sailing." 3

The 1871 version of this work, which is by far more indicative of parenthetical nuance than is the truncated 1867 rendering, reads as follows:

When I read the book, the biography famous,

And is this then (said I) what the author calls a man's life?

And so will some one when I am dead and gone write my life?

(As if any man really knew aught of my life,

Why even I myself I often think know little or nothing of my real life,

Only a few hints, a few diffused faint clews and indirections

I seek for my own use to trace out here.) $)^{4}$

The "indirections" by which Whitman encounters clues to his own life apply as well to the parenthetical indirection the reader encounters in pursuit of the meaning of "When I Read the Book." In this regard, the poem exemplifies the artistic practice, as described in "A Backward Glance O'er Travel'd Roads," whereby Whitman manages a work so that readers must enter its ambiance: "The reader will always have his or her part to do, just as much as I have had mine." ${ }^{5}$ Such a proto-Imagiste technique of indirection, 
described by Howard J. Waskow as "didacticism in reverse," directs the reader's participation in the generation of the meaning of the poem. The participatory reader thereby potentially becomes a secret sharer and collaborator with the poet, their mutual experience testimony (as we will see) to the Transcendentalist tenet that "in going down into the secrets of [one's] own mind [one] has descended into the secrets of all minds."7

Consider the opening line of the poem, apparently designed to encourage the nineteenth-century reader to anticipate a poem identifiable in terms of the encomium tradition. This likely expectation is augmented by the positioning of the word famous after the noun it modifies, rather than before the noun as in conversational English. Such standard poetic license, common in nineteenth-century verse, usually signals the poet's intention to manage rhyme and meter to suit the demands of some verse convention. Whitman, in short, directly indicates that he can write such conventional verse if he so wishes, and at the same time he indirectly leads unsuspecting readers toward the jolting reversal conveyed in the next line.

The syntactic wrenching of second line is indeed a jolt, not only converting the anticipated praise of the encomium tradition in the first line into unfashionable disapproval but also switching from the opening incomplete declarative sentence to the abrasive interrogative of the second line. And seated prominently in the middle of the second line-by way of the parenthetical expression "(said I)"-is the contentious narrator, intruding himself upon the reader's consciousness, already aroused as a result of a provocative question and a reversal of expectation. The "(said I)" narrator intrudes, moreover, in a manner that could be considered unnecessarily emphatic; for his presence is already amply implied by the interrogatory challenges to the unnamed biographer, the encomium tradition, the conventional verse techniques, and the reader's conformist expectations. On first sight, this intrusion amounts to a parenthetical insertion of the sort that represents a digression from the apparent main theme, at least as this theme of the famous biography is anticipated in the first line. Paradoxically, however, as the poem continues, this understanding of parenthetical insertion transposes with the inversion of focus from declarative to interrogative, from the seemingly disclosed biographical subject to the virtually undisclosable autobiographical poet; so that what initially appeared to be a digression from the explicit main theme at the commencement of the poem becomes an amplification - the other rhetorical possibility of a parenthetical insertionof the implicit "real" main theme by the conclusion of the poem.

The third line facilitates this shift of focus as the biographer, the subject of the biography, and the reader fade still further before the narrator's increasing emphasis on himself, even presumptively implying that he will be a likely candidate for a future biography, concerning which he already holds a preemptive contempt. Because biography necessarily stresses its subject's outward life, which is at best an opaque sign of the individual's inward life, the poet prefers autobiography as a better, albeit also inadequate, testament to one's inward life. And as the poet's comments trail off, interiorly retreating into a four-line parenthetical rumination, he seems to be speaking to himself much more than to any external audience. The audience, like the poet, is 
in effect reduced to an eavesdropper who inadvertently overhears the poet's inner thoughts and thereby unwittingly becomes a secret sharer.

In an important sense, the poet is his own best audience. He, like any other reader of the provisional, parenthetical autobiographical ruminations in his poem, only glimpses his inner "real life" as "a few hints, a few diffused faint clews and indirections." In fact, if the seemingly prolix "I often think" in the fifth line is perceived as an implicit parenthetical insertion, akin to the equally intrusive "(said I)" earlier, then at this point the poet not only appears to go deeper within himself but his elusive core-self also gives the impression of receding before his search for it. The clause "I often think" functions like a parenthetical insertion within a parenthetical insertion; and the intimation here is that even as the poet's voice stresses its temporal Iness, his "real life" eludes revelation as if it were ensconced deep within innumerable parentheses-like layers. If we see the graphic symbols for parentheses, ( ), as arcs of a circle not yet fully revealed as such, it is possible to liken Whitman's sense of the concentrically layered self in this poem to such standard Transcendentalist treatments of the circle as in, say, the hieroglyph of circulation in Emerson's "Spiritual Laws" or the mandala structure of Thoreau's Walden. For all three authors life is great circle-sailing, not only outwardly as one's life organically evolves in the course of time but especially inwardly as the self infinitely unfolds "by an internal industry and expansion" before its own self-inquiry. ${ }^{8}$

And this is Whitman's point, both thematically and artistically in "When I Read the Book": that the elusive core of being deep within the self is the same mysterious being outside the self. "The near explains the far," correspondingly, the truth without is also the truth within. But of the near and the far, at least in human terms, autobiographic delving within the circlelike layers of one's own self yields more-albeit at best "only a few diffused faint clews and indirections"- than does scrutinizing the outer signs of any life. If, simultaneously, interior truth is exterior truth, if a self-revealing poet is also his own witness, if we readers outside the poet are one with him on the inside, then equally paradoxically indirection can be a form of direction. In other words, an apparent parenthetical digression (a departure from some explicit or outward theme) can prove to be a parenthetical amplification (an enhancement of some implicit or inward theme). Although the mystery of being that is phenomenally suggested in both nature and human lives is the same mystery informing the self, it is difficult for humanity to read it as exterior sign. Going within - to mimic there the organic principle of expansion from within to without - cannot fully disclose the universal All, but this inward process at least provides an indirect, parenthetical encounter with the universal "real." And so the bi-polar thematics and parentheses-within-parentheses form of "When I Read the Book" urge the poet and the reader, as ultimately a mutual identity, to go "down into the secrets of [one's] own mind" and thereby "descend ... into the secrets of all minds"-that is, to sense the inferences of their mutual "real life" by receptively sailing among the infinitely regressive parenthetical circles within the self, an inward sailing that paradoxically is also great circle-sailing in the phenomenal world. 


\section{NOTES}

1 Alan Helms, "'Hints . . . Faint Clews and Indirections': Whitman's Homosexual Disguises," Walt Whitman: Here and Now, ed. Joann P. Krieg (Westport: Greenwood Press, 1985), 63; David Eberly, "A Serpent in the Grass: Reading Walt Whitman and Frank O'Hara," The Continuing Presence of Walt Whitman: The Life after the Life, ed. Robert K. Martin (Iowa City: University of Iowa Press, 1992), 75; James E. Miller, Jr., Walt Whitman (New York: Twayne, 1962), 16-17.

2 C. Carroll Hollis, Language and Style in Leaves of Grass (Baton Rouge: Louisiana State University Press, 1983), 119.

3 Henry David Thoreau, Walden and Civil Disobedience, ed. Owen Thomas (New York: W. W. Norton, 1966), 211.

4 Walt Whitman, Leaves of Grass, ed. Sculley Bradley and Harold W. Blodgett (New York: W. W. Norton, 1973), 8.

5 Whitman, 570.

6 Howard J. Waskow, Whitman: Explorations in Form (Chicago: University of Chicago Press, 1966), 113.

7 Ralph Waldo Emerson, "The American Scholar," Selections from Ralph Waldo Emerson, ed. Stephen E. Whicher (Boston: Houghton Mifflin, 1957), 74.

8 Thoreau, 15-16.

9 Emerson, 78. 